
\title{
R Reserach S Suare \\ Deciphering Diversity at er Loci for Diversification of Powdery Mildew Resistance in Pea
}

Devender K Banyal

COA, CSKHPKV

Himisha Dixit

COA, CSKHPKV

Jaya Chaudhary

COA, CSKHPKV

Anudeep B Malannavar

COA, CSKHPKV

Nisha Thakur ( $\square$ nishathakur81086@gmail.com )

COA, CSKHPKV

\section{Research Article}

Keywords: er1 gene, fungal pathogen, haplotypes, pea, resistant cultivars

Posted Date: January 19th, 2022

DOI: https://doi.org/10.21203/rs.3.rs-1239249/v1

License: (c) (1) This work is licensed under a Creative Commons Attribution 4.0 International License.

Read Full License 


\section{Abstract}

Agricultural biotechnology aims to scrutinize the field crops which feed amongst half of the world's population by improving their agronomic traits using various biotechnological tools. Pea- an important cash crop, rich in nutrients, but frequently infected with powdery mildew (fungal disease) that destroy the whole crop which causes the economy loss for growers. We therefore, targeted this research to find the pathogen resistant pea lines and further decipher the diversity at er locus among resistant pea lines. Screening for resistant pea lines was done with Erysiphe pisi isolates (Genebank submission: KX45 5922.1) under net house and green house conditions. Molecular studies revealed that Erysiphe resistant (er1) gene was present in 40 lines out of selected 50 pea lines and the mutational character was conferred up to 36 genotypes with 11 haplotype groups. The haplotype (gene) diversity (Hd) was found to be $0.5571 \pm 0.099$ SD and the nucleotide diversity $(\mathrm{Pi})$ was $0.0160 \pm 0.0042$ SD Majority of resistant lines (67\%) occurred in Hap-1, other remaining haplotypes (Hap 2-10) having 33\% resistant lines, each showing characteristic nucleotide substitutions with respect to reference PsML01 gene; genotypes from these divergent haplotypes can be used in pea resistance breeding to avoid genetic homogeneity and genetic vulnerability.

\section{Introduction}

During this global pandemic era, we are able to precise that the medical facilities become the priority for the life savior of the whole community. Although this is a universal talk, but to feed the whole community, agriculture plays an equal and important role in the well-being livelihood of the people across globally. Peeping back into history to till this pandemic situation, we can elaborate the role of various agricultural and horticultural crops to boost immunity against various diseases. E.g., Turmeric (Curcum), ajwain, ginger, garlic, among vegetables broccoli (anticancerous), lemon (vit c), all green leafy vegetables (rich in iron). The crops are not only known for their nutritive value; but also provide economy to farmers. These crops are grown in the whole world according to their geographical and climatic conditions. If we start our journey from North-west Himalayas, we pay our attention towards the Pea crop (Pisum sativum) which has been grown since many centuries for green pods and grains to meet the nutritional demands and economic upliftment of the growers. Nutritionally, pea crop comprises of protein (25\%), slowly digestive starch (50\%), sugars (12\%), amino acids, carbohydrates, vitamins (A and C), calcium and phosphorus [1] along with lysine [2]. An interesting feature of this crop which increase its value as being a vegetable crop, it can be canned, frozen, dehydrated or dried and thus becomes a pulse crop. Being monumental one, several preventive measures has been taken for crop protection which occurred due to biotic and abiotic stresses. Powdery mildew of pea is one of the common biotic stresses, which is caused by the Erysiphe pisi which reduces the crop yield up to 50 per cent by affecting the quality and quantity of green pods and dry seeds of pea [3] [4]. Management of this drastic disease becomes compulsion because the pathogen not only affected the grain and pods, but also reduced pea foliage up to $33-69$ per cent [5]. Banyal et al.2005 [6] developed disease resistant cultivars by studying pathogenic variability of E. pisi among various pea varieties. These resistant lines having er (Erysiphe resistant) locus having MLO gene 
(responsible for resistant mechanism in pea) which was detected using various molecular approaches. Present investigation therefore, carried out to find the presence of MLO gene among selected resistant cultivars of pea and deciphering diversity of ergene present among these resistant cultivars.

\section{Results}

\section{Identification of test isolate}

Morphological characteristics viz., hyphae, conidia, conidiophores, conidia size and conidiophore foot cells were studied on the detached leaves of host using stereo zoom microscope (Fig.1; Table 2). Attanayake et al. 2010 [7] described two groups of powdery mildew infected pea pathogen in combination of morphological and molecular characters. PCR amplification revealed an amplicon of approximately 560bp, (Fig. 2) which was further gel purified and lyophilized before sequencing. BLAST analysis of the sequences of test isolates P-1 (from pea) and P-2 (from clover) indicated that both the strains were placed in the phylogenetic lineage occupied by the genus Erysiphe along with species, pisi and trifolii, respectively (Fig.2). The 18S rRNA sequence strain has been deposited in the NCBI GeneBank (Accession number KX455922 and KX455923, respectively).

\section{Screening for resistant pea lines}

Previously, screening was done and selected 3 resistant lines were crossed with $\mathrm{JI}-2302$ (er1) and JI-2480 (er2) in 8 cross combinations viz., Jl-2480 x Acacia, JI-2480 x PMR-10, JI-2480 x EC-381866-1, JI-2480 x Lincoln, JI-2302 x Acacia, Jl-2302 x PMR-10, JI-2302 x EC-381866-1 and JI-2302 x Lincoln under nethouse and green house and description of infection was observed [6]. Resistant was governed in maximum cultivars due to presence of er1 gene (Table 3). We therefore, select er1 gene for further studies.

\section{Amplification studies}

A total of 50 pea lines were used for RNA extraction (Fig.3). cDNA prepared from RNA was further amplified by specific primers mentioned in material and methods. To achieve this many times repeated PCRs were carried out in all the samples to standardize the protocol. Out of 50 lines, amplification was possible with primer $3 \mathrm{~F}$ and $3 \mathrm{R}$ which produced 40 amplicons of variable size (250-300 bp) targeted that the er1 gene was present only in these lines. (Table 4; Fig 3).

\section{In silico analysis of gene sequences}

BLAST N search for homology of all the sequences of er1 gene corresponds to the gene present in Pisum sativum ML01 (ML01) mRNA, complete cds; homology queries values $\geq 90 \%$ and $E$ values near 0 for Nucleotide Blast analysis. Phylogenetic analyses separated the pea accessions into 3 groups. The major group A constituted by 32 accessions and the remaining 8 accessions were grouped as 6 and 2 in B and $\mathrm{C}$ group, respectively. Obtained tree was then saved to newick format and Fig Tree program was used for tree illustration (Fig.4) (http://tree.bio.ed.ac.uk/software/figtree/ ). 


\section{No. of haplotypes}

A total of 11 haplotypes were obtained and the frequency of haplotypes ranged from 1 to 24 . Hap-1 was the most abundant haplotype representing 24 genotypes including the reference genotype (FJ463618.1). The remaining haplotypes were represented by single genotype except Hap- 4 which is represented by 3 genotypes (Table 5). The Hap-1 having 23 genotypes showed 100 per cent similarity with reference genotype (FJ463618.1), hence does not have any base substitution w.r.t PsML01, whereas, Hap-2, 3, 4, 5, $6,7,8,9,10$ and 11 have $9,5,1,6,6,16,15,14,13$ and 6 base substitutions, respectively.

\section{Polymorphic sites}

The analysis of polymorphic sites was carried out using DNAsp VI, and total of 36 sequences were used with a total of 198 variable sites. The 47 polymorphic sites included 18 Singleton variable sites, out of which 17 were with two variants and one was with three variants. There were 29 Parsimony informative sites out of which 26 were with two variants and three with three variants. The analysis of polymorphic sites was further studied in detail using multiple sequence alignment. Multiple sequence alignment was carried out in MEGA-(software) using the tool Clustal W [8]. Each haplotype of evaluated resistant pea genotypes were compared with the reference genotype for any site with replacement, deletion and addition (Fig. 5).

\section{Haplotype diversity and Tajima's Test}

Haplotype diversity was calculated using DNAsp VI where haplotype (gene) diversity was of 0.5571 and Nucleotide diversity (per site) of 0.01606 (Table 6). Tajima's test also found to be statistically significant with Tajima's $D-2.09021$ at $P<0.05$. A median-joining network inferred from 40 set of sequences with 33 no. of active haplotypes was drawn. A value of zero was set for epsilon $(e=0)$ to calculate sparse networks quickly, or incrementally. Maximum no. of mutations (29) was found at character 941 and least no. of mutations (1) were ranged at characters $992-1190$ (Fig. 6).

\section{Discussion}

Till date, various research work has been carried out for the management of powdery mildew in pea plant [9] [10] [11]. Knowing the importance of this vegetable crop by exploring the literature we therefore, continued this research by deciphering the diversity at er loci in pathogen resistant pea lines [12] which was screened under invitro conditions [13]. Pathogen causing powdery mildew was collected from Northwest Himalayas in which the maximum number of isolates were collected from Lahul area of transHimalayas [14] [15]. Molecular and morphological identification of test pathogen (from pea leaf and pea clover) corresponds to genus Erysiphe with species pisi and trifoli, respectively [16] [7] [17]. Screening was done under net-house and green house conditions where description of infection was recorded [6]. Selected resistant lines were crossed with the resistant carrier lines JI-2302 (er1) and JI-2480 (er2), respectively [11] [18] [19]. Maximum of resultant cultivars showed the character of $\mathrm{JI}-2302$, hence governed by er1 gene [20] [21]. Reviewing the available literature, it has been found that er1 gene provides 
a stable and resistance to E. pisi [22] [11] [23], thus can be used for breeding aspect. To reveal the presence of er1 gene, RNA isolation was carried out the 50 lines of pea [21]. RNA was extracted manually and the cDNA sequences of their PsMLO genes at er1 locus were targeted [24] [25] [21]. Out of four powdery mildew gene specific designed primers, primer PsMLO3F and PSMLO3R [26] successfully amplified the target er -1 gene in 40 amplicons (250-300bp) which were further, purified and sequenced. Positive results indicated that PSMLO gene was expressed with primer $3 \mathrm{~F}$ and $3 \mathrm{R}$ only after infection of $\mathrm{E}$. pisi whether after 4 days / 8 days which can be related that this gene is inducive in nature [27]. BLAST N search for homology of all the sequences of er 1 gene corresponded to the reference gene present in Pisum sativum ML01 (ML01) mRNA, complete cds; homology queries values

$\geq 90 \%$ and E values near 0 [28] [29]. Phylogenetic tree classified the pea accessions into 3 groups in which major group A constituted by 32 accessions and remaining 8 accessions were grouped as 6 and 2 in $\mathrm{B}$ and $\mathrm{C}$ group, respectively. In our analysis, largest clade comprises of major group A correspond $\geq$ $90 \%$ of similarity with Pisum sativum MLO1 sequences. It can be supported that these sequences having MLO genes analogue of er 1 gene present in these accessions can be used for future breeding programs. A total of 11 haplotype groups were found where the frequency of haplotypes ranged from 1 to 24 . Hap-1 was the most abundant haplotype representing 24 genotypes including the reference genotype (FJ463618.1) which revealed no base substitution w.r.t PsML01. The genotypes having er1 gene grouped in Hap-1 represents the resistant alleles passed from resistant carriers linked together without any substitutions. In case of Hap-2, 3, 4, 5, 6, 7, 8, 9, 10 and 11 have 9, 5, 1, 6, 6, 16, 15, 14, 13 and 6 base substitutions, respectively were found at MLO locus thus showing the diversity in the er1 gene substitutions. Each haplotype of evaluated resistant pea genotypes were compared with the reference genotype for any site with replacement, deletion and addition. The genotypes from these divergent haplotypes can be used in pea resistance breeding to avoid genetic homogeneity and genetic vulnerability. Haplotype diversity was calculated using DNAsp VI A low value of nd (0.01606) revealed that these resistant lines can't be affected from environmental conditions. Tajima's test also found to be statistically significant with Tajima's D -2.09021 at $\mathrm{P}<0.05$. Network revealed the present of er1 gene in great majority of lines shared identical haplotype with the reference PSMLO1 gene thereby suggesting that these lines has originated from a common ancestor.

\section{Materials And Methods}

\section{Collection and identification of test pathogen}

A total of 24 isolates of powdery mildew were collected from North-west Himalayas out of which maximum isolates were collected from 15 different locations of trans-Himalayan Lahul Spiti region. These were purified and maintained in greenhouse for further studies. The pathogen causing pea powdery mildew was identified on the basis of morphological characteristics viz., hyphae, conidia, conidiophores, conidia size and conidiophore foot cells. Further, polyphasic analysis of strain was done with 18S rRNA gene sequence. The sequence obtained was submitted to NCBI gene bank for accession number. 


\section{Screening for resistance}

Screening for resistance against identified fungal pathogen was done from a panel of 310 pea lines comprising of exotic and indigenous germplasm collected from different sources (CSK HPKV Palampur, NBPGR New Delhi, PAU Ludhiana and IIPR Kanpur) were evaluated in net-house as well as on detached leaves under in vitro conditions [30]. The identified resistant lines along with susceptible ones were crossed with known recessive genes er1 and er2 present in Jl-2302 (er1) and JI-2480 (er2) lines under greenhouse. Further, cultivars having resistance respective er gene were selected to determine the allelic diversity at erlocus.

\section{RNA extraction}

A total of 50 pea lines were selected for RNA isolation using trizol method [31]. RNA was extracted from fresh leaves (without inoculation of Erysiphe pisi) and inoculated leaves (after 4 and 8 days of fungal inoculation), to check whether this gene is constitutive or inductive.

\section{cDNA Synthesis and amplification studies}

40 ug of RNA was used cDNA amplification using reverse transcriptase enhancer, $5 x$ cDNA buffer, dNTP mix (5Mm each), verso enzyme as per the instructions recommended on Verso enzyme cDNA kit. PCR reaction mix was incubated at $42^{\circ} \mathrm{C}$ for 30 minutes. Further, reaction was terminated at $95^{\circ} \mathrm{C}$ for 2 minutes. For amplification of cDNA, PCR plates were filled with reaction mixture containing $5 \mathrm{Xbuffer}$, $25 \mathrm{mM} \mathrm{MgCl} 2,10 \mathrm{mM}$ dNTPs, $0.5 \mathrm{mM}$ of each specific-designed PsMLO primer (Table 1), $5 \mathrm{U}$ Taq DNA polymerase with template cDNA. Amplification profile consisted 1 cycle at $95^{\circ} \mathrm{C} / 5 \mathrm{~min} ; 37$ cycles at $95^{\circ} \mathrm{C} / 30 \mathrm{~s}, 50^{\circ} \mathrm{C} / 30 \mathrm{~s}$ and $72^{\circ} \mathrm{C} / 1 \mathrm{~min} 20 \mathrm{sec} ; 1$ cycle at $72^{\circ} \mathrm{C} / 7 \mathrm{~min}$; hold at $4^{\circ} \mathrm{C} / \infty$. The PCR products were separated on agarose gel (1.2\%) and the targeted amplicons were purified and sequenced at the SciGenome Labs Private Ltd. Cochin, Kerala - INDIA.

\section{In silico analysis of gene sequences}

Homology of gene sequences were analyzed using online bioinformatic tools available in NCBI database in FASTA programme. BLASTN was used for sequence comparison on NCBI genomic database (http://www.ncbi.nlm.nih.gov/blast/Blast.cgi) . Phylogenetic analysis was conducted in MEGA 5.0 [32] and genetic parameters such as haplotype diversity and total number of mutations, Indel polymorphism were calculated using DnaSP version 5.10 [33]. Network v 4.61 was used to construct Median joining (MJ) [34] network of the haplotypes

(http://www.fluxus-engineering.com).

\section{Conclusion}

For management of fungal diseases in crops, many strategies including conventional as well as nonconventional approaches are frequently used. From our research we identified the resistant cultivars in 
pea crops which meet the demand of low and marginal farmers and reduces the use of chemicals in a controlled manner.

\section{Declarations}

\section{Acknowledgements}

Authors are thankful to funding agency SERB, Ministry of Science and Technology Department of Science and Technology, New Delhi for providing financial assistance during the entire period for completion of research.

\section{Statements}

The authors declared that they have no conflict of interest in the publication

The datasets analysed during the current study are available in the NCBI Nucleotide repository, https://www.ncbi.nlm.nih.gov/nuccore/1131300078, https://www.ncbi.nlm.nih.gov/nuccore/1131300079

with accession numbers GenBank: KX455922.1 and GenBank: KX455923.1 respectively.

All ethical guidelines followed during collection of plant material from relevant mentioned institutes/Universities. Details of the plant material are already published (Rana et al., 2013; Banyal et al., 2015)

Rana, J. C., Banyal, D.K.,Sharma, K.D., Sharma, Manish K., Gupta, S. K. and Yadav, Satish K.2013. Screening of pea germplasm for resistance to powdery mildew. Euphytica. 189:271-282

Banyal, D. K., Chaudhary, Jaya and Singh, Amar.2015. Evaluation of pea (Pisum sativum) germplasm for inheritance of resistance to powdery mildew (Erysiphe pisi). Indian Phytopathology. 68: 166-171

\section{References}

1. Smýkal, P. et al. Pea (Pisum sativum L.) in the genomic era. Agronomy vol. 2 (2012).

2. Avci, M. A. \& Ceyhan, E. Correlations and genetic analysis of pod characteristics in pea (Pisum sativum L.). Asian Journal of Plant Sciences 5, (2006).

3. Dixon, G.R. Powdery mildew of vegetables and allied crops in: Speaure DM (ed.) Powdery mildew. Academic Press, San Diego (1987).

4. Nisar, M., Ghafoor, A., Khan, M. R. \& Qureshi A.S. Screening of Pisum sativum L. germplasm against Erysiphe pisi Syd. Acta Biologica Cracoviensia Series Botanica 48, (2006).

5. Suneetha, T., Gopinath, S.M \& Naik, S.L. Identification of resistance gene analogs (RGAs) linked to powdery mildew resistance in Peas. Int. J. Inno. Res. Adv.Eng 6, 33-36 (2014). 
6. Banyal, D.K., Singh, A. \& Tyagi, P. Pathogenic variability in Erysiphe pisi causing powdery mildew of pea. Him. J. Ag. Res 31, 87-92 (2005).

7. Attanayake, R. N., Glawe, D. A., McPhee, K. E., Dugan, F. M. \& Chen, W. Erysiphe trifolii - a newly recognized powdery mildew pathogen of pea. Plant Pathology 59, https://doi.org/10.1093/bioinformatics/btm404 (2010).

8. Larkin, M. A. et al. Clustal W and Clustal X version 2.0. Bioinformatics 23, (2007).

9. Heringa KJ, Vannorel A \& Tazelaar MF. Resistance to powdery mildew (Erysiphe polygoni DC) in peas (Pisum sativum L.). Euphy 13, 163-169 (1969).

10. Gupta, SK \& Thind, TS. Disease problems in vegetable production. Kalyani Publishers 342-342 (2006).

11. Tiwari, K. R., Penner, G. A. \& Warkentin, T. D. Inheritance of powdery mildew resistance in pea. Canadian Journal of Plant Science 77, (1997).

12. Chaudhary, J. \& Banyal, D.K. Evaluation of pea genotypes for resistance against powdery mildew caused by Erysiphe pisi. Ind. Phytopatho 70, 69-74 (2017).

13. Rana, J. C. et al. Screening of pea germplasm for resistance to powdery mildew. Euphytica 189, (2013).

14. Banyal, D. K. \& Rana, S. K. Fungicidal spray schedule for the management of pea powdery mildew. $J$ Mycol. Pl. Patho/ 33, 302-304 (2003).

15. Takamatsu, S., Ito, H., Shiroya, Y., Kiss, L. \& Heluta, V. First comprehensive phylogenetic analysis of the genus Erysiphe (Erysiphales, Erysiphaceae) I. The Microsphaera lineage. Mycologia 107, (2015).

16. Kiss, L. Advances in the identification of emerging powdery mildew fungi using morphological and molecular data. Acta Microbiologica et Immunologica Hungarica 49, (2002).

17. Baiswar, P. et al. Molecular evidence of Erysiphe pisi on pea and E. trifoliorum on white clover in northeast India. Australasian Plant Disease Notes 10, (2015).

18. Fondevilla, S., Carver, T. L. W., Moreno, M. T. \& Rubiales, D. Identification and characterization of sources of resistance to Erysiphe pisi Syd. in Pisum spp. Plant Breeding 126, (2007).

19. Fondevilla, S., Chattopadhyay, C., Khare, N. \& Rubiales, D. Erysiphe trifolii is able to overcome er 1 and Er3, but not er2, resistance genes in pea. European Journal of Plant Pathology 136, (2013).

20. Sun, S. et al. Resistance to powdery mildew in the pea cultivar Xucai 1 is conferred by the gene er1. Crop Journa/ 3, (2015).

21. Sun, S. et al. A novel er1 allele and the development and validation of its functional marker for breeding pea (Pisum sativum L.) resistance to powdery mildew. Theoretical and Applied Genetics 129, (2016).

22. Fondevilla, S., Rubiales, D., Moreno, M. T. \& Torres, A. M. Identification and validation of RAPD and SCAR markers linked to the gene Er3 conferring resistance to Erysiphe pisi DC in pea. Molecular Breeding 22, (2008). 
23. Fondevilla, S., Carver, T. L. W., Moreno, M. T. \& Rubiales, D. Macroscopic and histological characterisation of genes er 1 and er2 for powdery mildew resistance in pea. European Journal of Plant Pathology 115, (2006).

24. Zeng L, Li MQ \& Yang XM. Identification of resistance of peas resources to powdery mildew. Grass. Turf 32, 35-38 (2012).

25. Wang, Z. Y. et al. Identification of powdery mildew resistance gene in pea line X9002. Acta Agronomica Sinica(China) 41, (2015).

26. Sun, S. et al. Two novel er1 alleles conferring powdery mildew (Erysiphe pisi) resistance identified in a worldwide collection of pea (Pisum sativum L.) germplasms. International Journal of Molecular Sciences 20, (2019).

27. Büschges, R. et al. The barley Mlo gene: A novel control element of plant pathogen resistance. Cell 88, (1997).

28. Filiz, E. \& Vatansever, R. Genome-wide identification of mildew resistance locus O (MLO) genes in tree model poplar (Populus trichocarpa): powdery mildew management in woody plants. European Journal of Plant Pathology 152, 95-109 (2018).

29. Kusch, S., Pesch, L. \& Panstruga, R. Comprehensive phylogenetic analysis sheds light on the diversity and origin of the MLO family of integral membrane proteins. Genome Biology and Evolution 8 , (2016).

30. Banyal, D.K., Singh, A., Upmanyu, S., Chaudhary, J. \& Sharma, P. N. Diversity analysis of Erysiphe pisi populations causing pea powdery mildew in Himachal Pradesh. Indian Phytopathology 67, 263-267 https://doi.org/10.1038/nprot.2006.83 (2014).

31. Chomczynski, P. \& Sacchi, N. The single-step method of RNA isolation by acid guanidinium thiocyanate-phenol-chloroform extraction: Twenty-something years on. Nature Protocols 1, https://doi.org/10.1093/molbev/msr121 (2006).

32. Tamura, K. et al. MEGA5: Molecular evolutionary genetics analysis using maximum likelihood, evolutionary distance, and maximum parsimony methods. Molecular Biology and Evolution 28, https://doi.org/10.1093/molbev/msx248 (2011).

33. Rozas, J. et al. DnaSP 6: DNA sequence polymorphism analysis of large data sets. Molecular Biology and Evolution 34, (2017).

34. Bandelt, H. J., Forster, P. \& Röhl, A. Median-joining networks for inferring intraspecific phylogenies. Molecular Biology and Evolution 16, https://doi.org/10.1111/j.1365-3059.2010.02306.x (1999).

\section{Tables}

\section{Table 1 List of primers used for amplification}




\begin{tabular}{|ll|}
\hline Primer Name & Sequence (5'-3') \\
\hline PsML0 1 FP & ATGGCTGAAGAGGGAGTTAAGGA \\
\hline PsML01RP & CTAATTGCTCCCTAAGTGGCG CT \\
\hline PsML02FP & CCTCGGAGAATTCTTGCTAC \\
\hline PsML02RP & TCCACAAATCAAGCTGCTACC \\
\hline PsML03FP & TCTGGCTCTTCACAGTGCTT \\
\hline PsML03RP & TGTGGAAGCAAGAGGTTATGG \\
\hline PsMLOEX5FP & ATGAGGAAGTGGAAGACTTGGGA \\
\hline PsML015EXRP & GCTTTTTGGCTGTGTGGTGCCAG \\
\hline
\end{tabular}

Table 2 Microscopic observations

\begin{tabular}{|ll|}
\hline Characters & Test Pathogen \\
\hline Hyphae & Straight, branched, septate and hyaline \\
\hline Conidia & Ellipsoid, cylindrical, ovoid shaped, hyaline and produced in chains \\
\hline Conidiophores & Erect, straight, hyaline, arise vertically from the hyphae on the host surface \\
\hline Foot cells & Cylindrical and decreased in width from base to the top \\
\hline Cleistothecia & Spherical, gregarious, dark brown in colour and dispersed in mycelial web \\
\hline Conidial (LXW) & $25.5-52 \times 11-18 \mu \mathrm{m}$ \\
\hline Conidiophores(LXW) & $22-50 \times 7-10.5 \mu \mathrm{m}$ \\
\hline Foot cells (LXW) & $17.5-28 \times 7-10 \mu \mathrm{m}$ \\
\hline Cleistothecia diameter & $87.5-133 \mu \mathrm{m}$ \\
\hline
\end{tabular}

Table 3 Evaluation of $F_{1}$ population to study the allelic relationship with known ergenes against pea powdery mildew caused by Erysiphe pisi 


\begin{tabular}{|c|c|c|c|}
\hline S.No. & Cross & Infection Type & Reaction Type \\
\hline 1. & Jl-2480 (er2) x Acacia & 2 & Resistant (R) \\
\hline 2. & Jl-2480 x PMR-10 & 3 & Susceptible (S) \\
\hline 3. & JI-2480 x EC-381866-1 & 3 & $S$ \\
\hline 4. & Jl-2480 x Lincoln & 4 & $S$ \\
\hline 5. & Jl-2302 (er1) x Acacia & 3 & $S$ \\
\hline 6. & JI-2302 x PMR-10 & 2 & $\mathrm{R}$ \\
\hline 7. & JI-2302 x EC-381866-1 & 2 & $\mathrm{R}$ \\
\hline 8. & JI-2302 x Lincoln & 4 & s \\
\hline
\end{tabular}

Table. 4 No. of amplified pea lines 
S.No. Pea Genotypes

\begin{tabular}{|c|c|}
\hline 1. & 1P-1287 \\
\hline 2. & 4P-995 \\
\hline 3. & 5P-1395-2 \\
\hline 4. & 7P-1301 \\
\hline 5. & 8P-1805 \\
\hline 6. & 9HFP-4 \\
\hline 7. & 10P-1806 \\
\hline 8. & 11P-1804 \\
\hline 9. & 12P-1820 \\
\hline 10. & 14P-144-10 \\
\hline 11. & $15 P-1280-4$ \\
\hline 12. & 16Р-668-1 \\
\hline 13. & 17P-1707 \\
\hline 14. & $18 \mathrm{P}-48$ \\
\hline 15. & 19P-1610-9 \\
\hline 16. & $20 P-1436-9$ \\
\hline 17. & 21P-1813 \\
\hline 18. & 22P-1377 \\
\hline 19. & 23P-1422-1 \\
\hline 20. & 24P1436-8 \\
\hline 21. & 25P1610-2 \\
\hline 22. & 26P-1506 \\
\hline 23. & 27P-1811 \\
\hline 24. & $28 \mathrm{P}-1440-20$ \\
\hline 25. & 29P-1516 \\
\hline 26. & 30P-179 \\
\hline 27. & 31IPF-99-25 \\
\hline 28. & 32PKPMR-400 \\
\hline
\end{tabular}


29. 39DPP-139-3

30. 40DPPMR-09-1

31. 42LFP-517

32. 43LFP-575

33. 45LFP-571

34. 48LFP-577

35. 50PB-29B

36. 51DPP-362

37. 52ACACIA

38. $55 \mathrm{MR} B I G$

39. 56KMNR-894

40. 59DMR-11

Table 5. Frequency distribution of different PsML01 haplotypes detected amongst the resistant pea lines 


\begin{tabular}{|c|c|c|c|}
\hline Hap\# & Frequency & Lines & $\begin{array}{l}\text { No of base } \\
\text { substitution(s)w.r.t. } \\
\text { reference } \\
\text { PsML01gene }\end{array}$ \\
\hline $\begin{array}{l}\text { Hap- } \\
1\end{array}$ & $24(23+1)$ & $\begin{array}{l}\text { FJ463618.1, P-1287, P-1820, P-1516, P-144-10, P-1707, } \\
\text { P-1610-9, P-1377, P-1506, DPMR-09-01, P-179, P-KPMR- } \\
\text { 400, P-1440-20, LFP-575, LFP-571, ACACIA, MR_BIG, P- } \\
\text { 1280-4, P-1422-1, P-1610-2, P-1436-8, P-1806, P-1813, } \\
\text { DMR-11 }\end{array}$ & 0 \\
\hline $\begin{array}{l}\text { Hap- } \\
2\end{array}$ & 1 & P-1804 & 9 \\
\hline $\begin{array}{l}\text { Hap- } \\
3\end{array}$ & 1 & P-995 & 5 \\
\hline $\begin{array}{l}\text { Hap- } \\
4\end{array}$ & 3 & HFP-4 P-48 KMNR-894 & 1 \\
\hline $\begin{array}{l}\text { Hap- } \\
5\end{array}$ & 1 & P-668-1 & 6 \\
\hline $\begin{array}{l}\text { Hap- } \\
6\end{array}$ & 1 & P-1811 & 6 \\
\hline $\begin{array}{l}\text { Hap- } \\
7\end{array}$ & 1 & IPF-99-25 & 16 \\
\hline $\begin{array}{l}\text { Hap- } \\
8\end{array}$ & 1 & DPP-139-3 & 15 \\
\hline $\begin{array}{l}\text { Hap- } \\
9\end{array}$ & 1 & LFP-517 & 14 \\
\hline $\begin{array}{l}\text { Hap- } \\
10\end{array}$ & 1 & LFP-577 & 13 \\
\hline $\begin{array}{l}\text { Hap- } \\
11\end{array}$ & 1 & PB-29-B & 6 \\
\hline
\end{tabular}

Table 6. Haplotype diversity and Tajma test 


\begin{tabular}{|ll|}
\hline Haplotype (gene) diversity, Hd & $\mathbf{0 . 5 5 7 1}$ \\
\hline Standard Deviation of Haplotype diversity & 0.099 \\
\hline Nucleotide diversity (per site), Pi & 0.01606 \\
\hline Standard deviation of Pi & 0.00462 \\
\hline Average number of nucleotide differences, $\mathbf{k}$ & 5.20317 \\
\hline Number of polymorphic (segregating) sites & 47 \\
\hline $\begin{array}{l}\text { total number of mutations (eta) } \\
\text { tajima's d }\end{array}$ & 51 \\
\hline
\end{tabular}

\section{Figures}

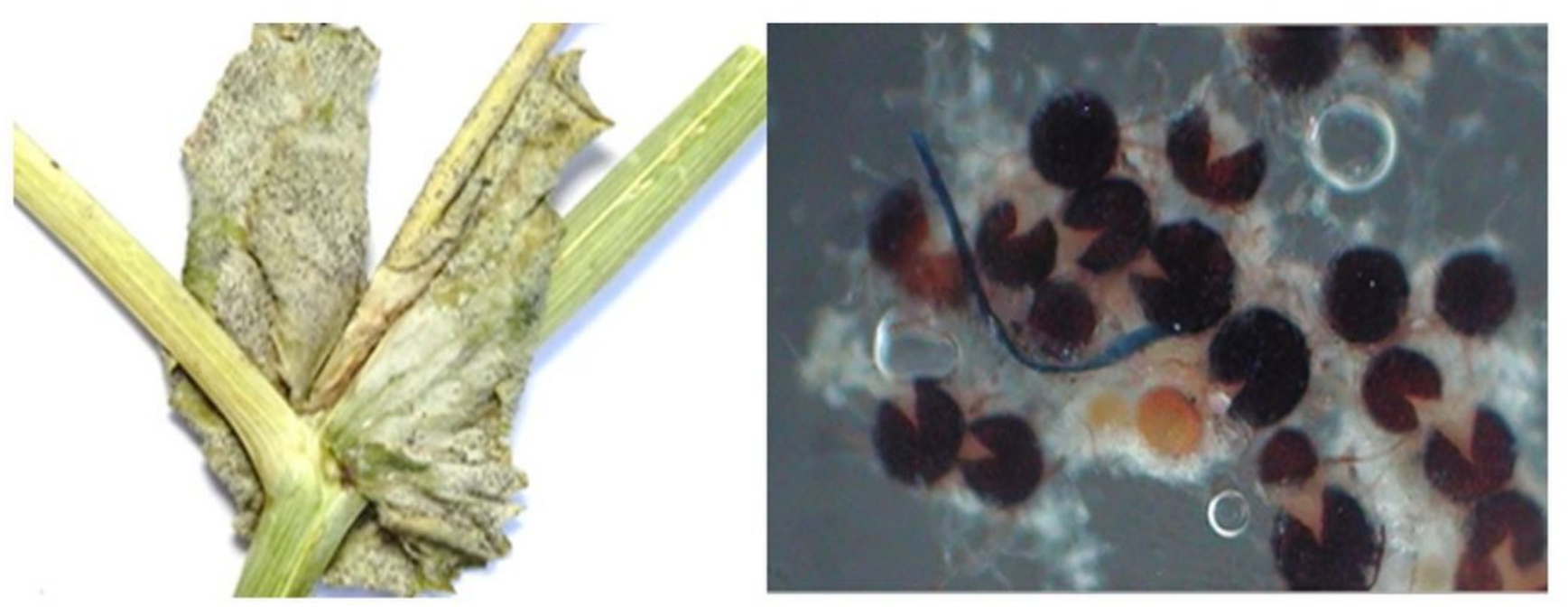

Figure 1

Microscopic view of fungal cleistothecia 


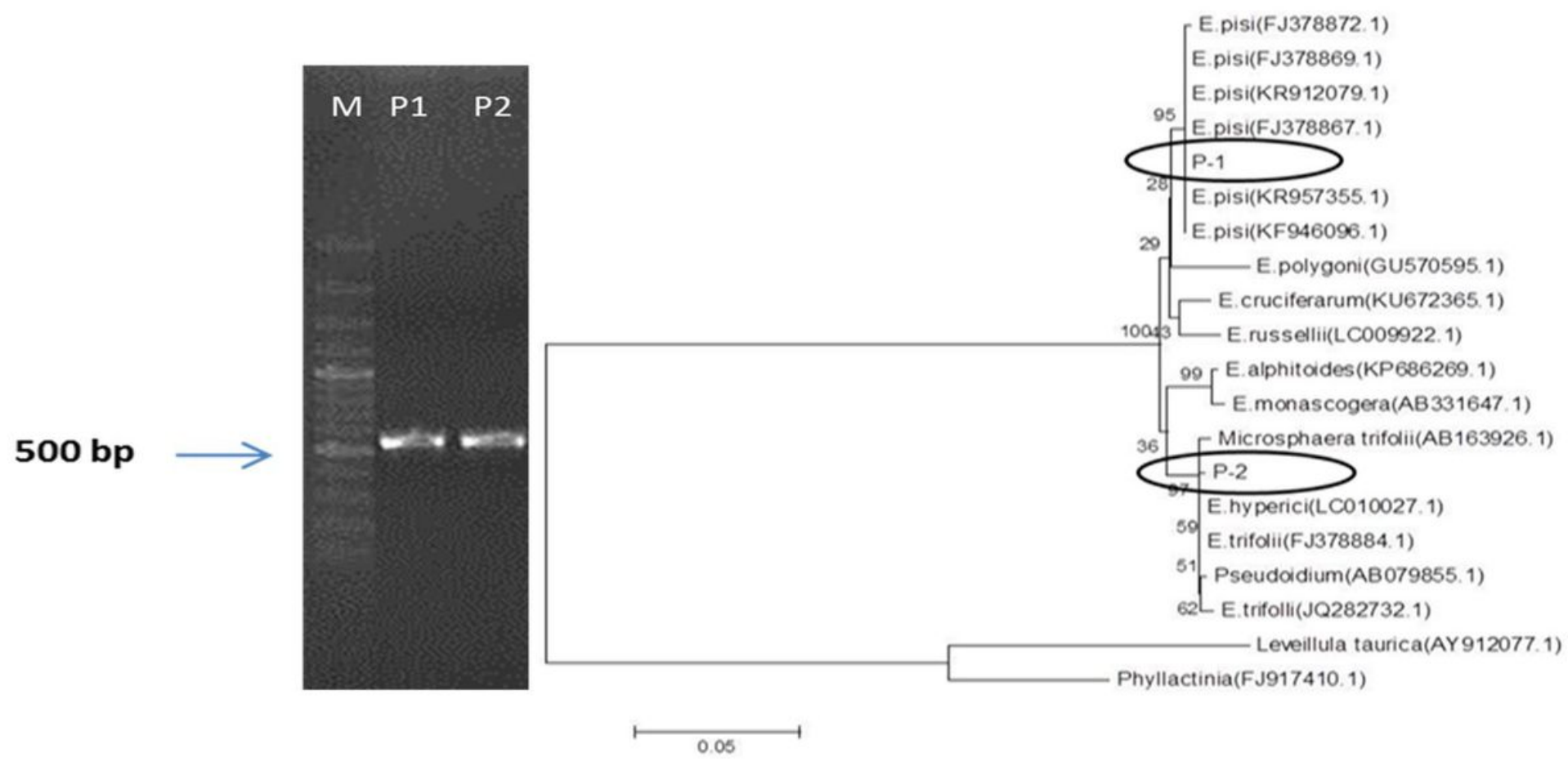

Figure 2

rDNA region amplified using Erysiphe specific primers (M: $1 \mathrm{~Kb}$ ladder; fungal isolate $\mathrm{P}-1$ and $\mathrm{P}-2$ along with tree phylogeny of P-1 :Erysiphe pisi, P-2: Erysiphe trifolii

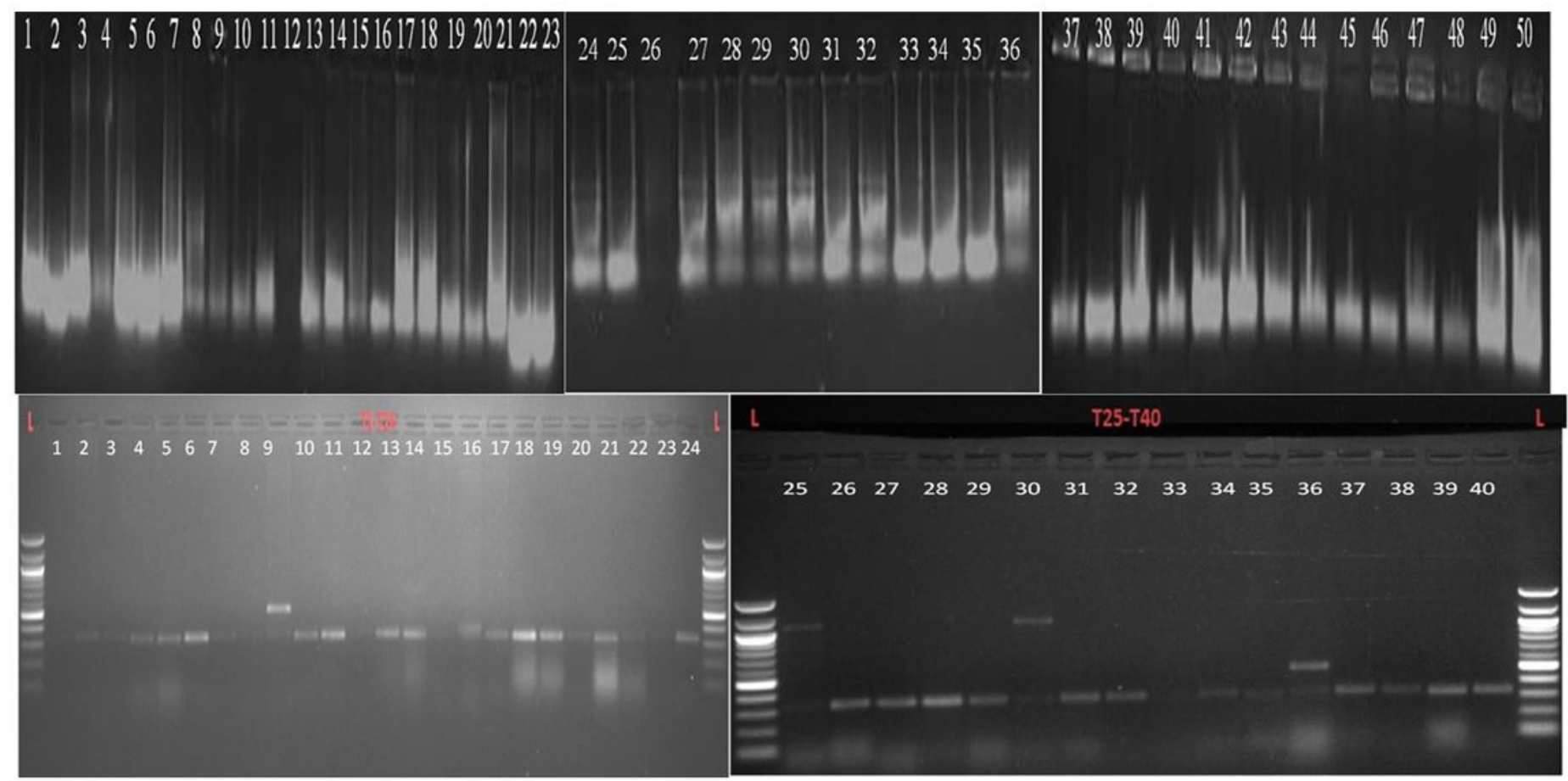

Figure 3 
RNA isolation (1-50) and amplification of pea lines (1-40)

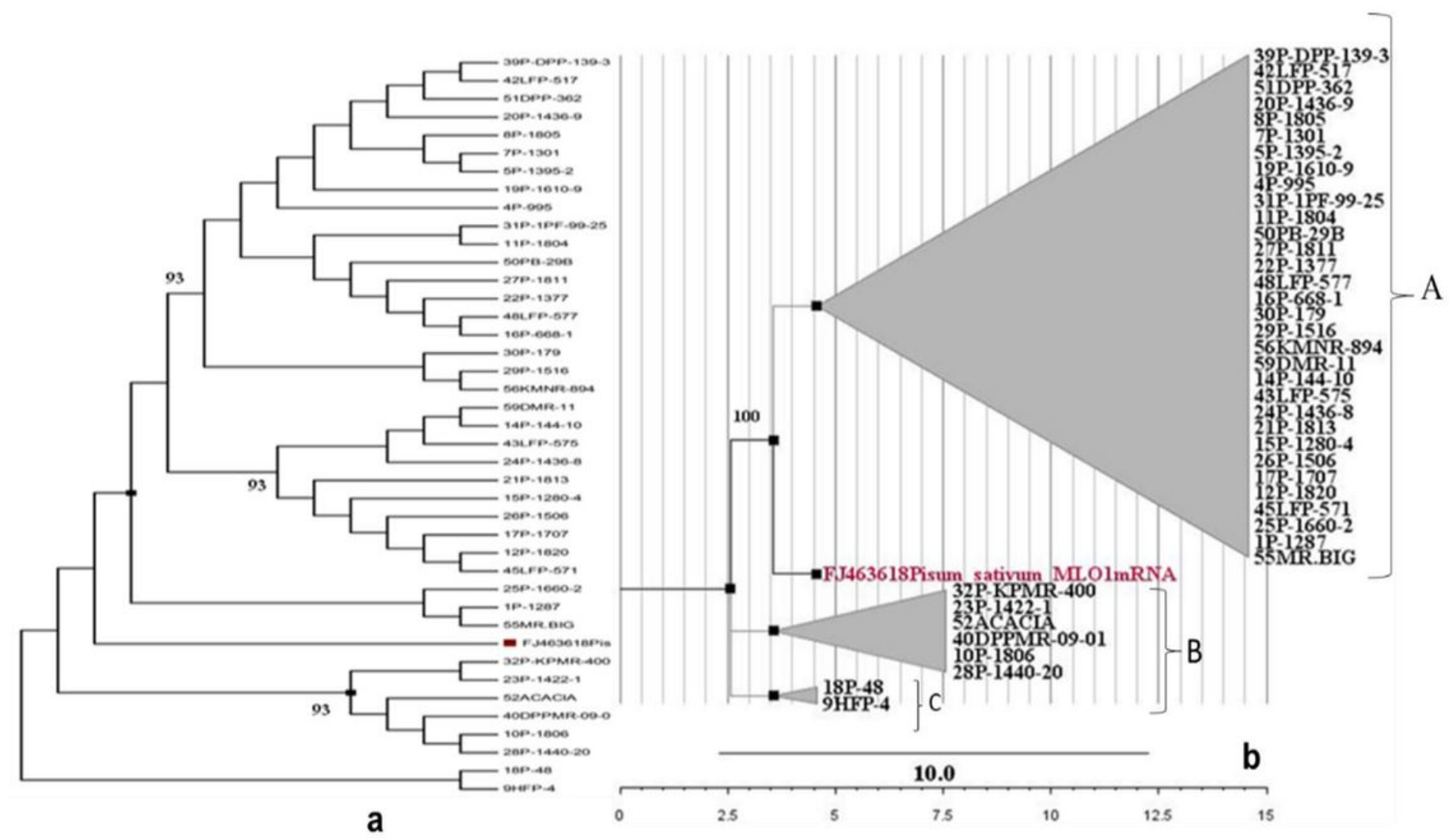

Figure 4

$\mathrm{NJ}$ tree based on MLO sequences. Posterior probabilities of the main clades above 0.93 (a) and bootstrap values in $\%(b)$ are indicated at the nodes (100). Designation includes pea lines number and name 


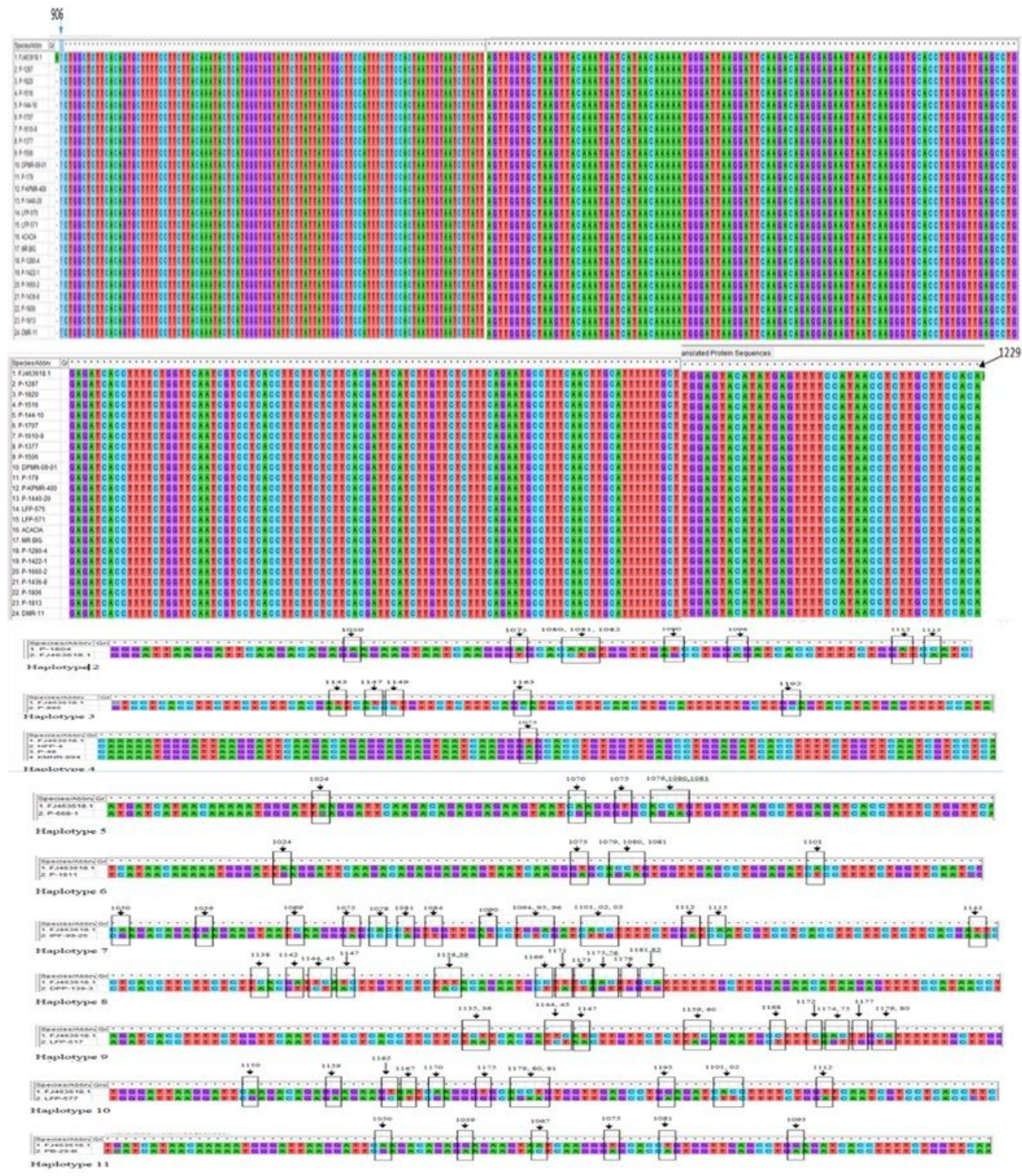

\section{Figure 5}

Sequence alignment of MLO gene (906-1229bp) of powdery mildew resistant pea accessions belonging to Haplotype 1-11 with reference sequence FJ463618.1 
Median joining network with median vector (red color dots), mutated characters (red color taxa) and sequence frequency (yellow color dots)

\section{Supplementary Files}

This is a list of supplementary files associated with this preprint. Click to download.

- SupplementaryFiles.pdf 